\title{
STRATEGIE REGULACJI EMOCJI I INKLINACJA AUTONARRACYJNA A EFEKTYWNOŚĆ ZAWODOWA
}

\author{
Marta Jaroszewska, marta.jarosh@gmail.com \\ Szkoła Wyższa Psychologii Społecznej w Warszawie \\ Ul. Chodakowska 19/31, 03-815 Warszawa
}

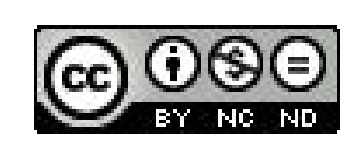

\section{STRESZCZENIE}

Celem niniejszego artykułu jest przedstawienie związków pomiędzy strategią regulacji emocji i inklinacją autonarracyjna, a efektywnością zawodowa, ze szczególnym uwzględnieniem wyników przeprowadzonego badania korelacyjnego. Badaniem objęci zostali konsultanci call center, których zadania zawodowe wymagają sprawnego radzenia sobie z sytuacjami emocjonalnie trudnymi. Uzyskane wyniki pozwalają przypuszczać, że tłumienie emocji wpływa negatywnie na poziom wykonywanych zadań.

Słowa kluczowe: regulacja emocji, przeformułowanie poznawcze, tłumienie emocji, inklinacja autonarracyjna, efektywność zawodowa, narracyjna kontrola zachowania, call center

\section{Emotion regulation strategies, narrative inclination and work performance}

\section{Abstract}

The present paper discusses some of the research findings about relationships between emotion regulation strategies, narrative inclination and job performance. The article presents the data from the study conducted among call centre agents working in environment that involves high skills in coping with emotions. The data indicate a negative correlation between suppression and job performance.

Key words: emotion regulation, cognitive reappraisal, suppression, narrative inclination, job performance, narrative action control, call centre

\section{WSTĘP}

Emocje, jako nieodłączny element funkcjonowania każdego człowieka, nadają jego życiu nie tylko pewien koloryt, ale przede wszystkim pozwalają na orientację w otaczającej rzeczywistości. Niejednokrotnie także determinują jego działania, pełniąc funkcję motywacyjna. Efektywne funkcjonowanie emocjonalne oraz dobrostan psychiczny, jak twierdzi John D. Mayer, zależą od zdolności w zakresie percepcji własnych i cudzych emocji, umiejętności ich wykorzystywania, rozumienia oraz regulowania ${ }^{1}$. Regulacja emocji obejmuje zarówno samo doświadczanie emocji, jak i ich ekspresję oraz przebiegać może na różnych poziomach. Jednostka może wybierać określone sytuacje lub ich unikać, sterować swoją uwaga, selekcjonować, bądź przekształcać napływające informacje, a także ujawniać lub nie, doświadczane emocje. Mechanizmy regulacji emocji wydają się szczególnie interesujące ze względu na ich doniosłe znaczenie dla różnych aspektów funkcjonowania człowieka, m.in. dla radzenia sobie w sytuacjach zawodowych, co znajduje odzwierciedlenie w wynikach wielu badań, przeprowadzonych w ostatnich latach ${ }^{2}$. W zależności od indywidualnych preferencji, ludzie stosują różne strategie regulacji emocji. Zgodnie z modelem James'a Grossa strategie te mogą być skoncentrowane na poprzedzaniu, zachodzić zanim jeszcze dojdzie do wzbudzenia emocji, lub dotyczyć zmiany ekspresji emocji, z którą mamy do czynienia wówczas, gdy doszło już do jej pojawienia się. Wyniki badań w zakresie efektywności stosowania poszczególnych strategii dla funkcjonowania człowieka, nie dają jednoznacznych rozstrzygnięć, wiele z nich wskazuje jednak na dobroczynny wpływ stosowania strategii przeformułowania poznawczego, w przeciwieństwie do strategii opartej na tłumieniu, m.in. dla radzenia

\footnotetext{
1 P. Salovey, John D. Mayer, Emotional Intelligence, "Imagination, Cognition And Personality" 1989, nr 3, s. 185-211.

2 A. A. Grandey, Emotion regulation in the workplace: A new way to conceptualize emotional labor, "Journal of Occupational Health Psychology" 2000, nr 5, s. 95-110; A. A. Grandey, G. M. Fisk, D. D. Steiner, Must "service with a smile" be stressful? The moderating role of personal control for American and French employees, "Journal of Applied Psychology" 2005, nr 90, s. 893-904; J. M. Diefendorff, E. M. Richard, J. Yang, Linking emotion regulation strategies to affective events and negative emotions at work, "Journal of Vocational Behavior" 2008, nr 73, s. 498-508; P. Totterdall, D. Holman, Emotion regulation in customer service roles: testing a model of emotional labor, "Journal of Occupational Health Psychology" 2003, nr 8, s. 55-73.

3 J. Gross, Handbook of emotion regulation, New York 2009, s. 13.
} 
sobie w sytuacjach zawodowych ${ }^{4}$. Istotne jest więc lepsze poznanie mechanizmu tych zależności. W niniejszym artykule formułuję hipotezę dotyczącą istnienia związku pomiędzy preferowaniem strategii regulacji emocji polegającej na przeformułowaniu poznawczym, a inklinacją autonarracyjną. Inklinacja autonarracyjna, jak definiuje ją Emilia Soroko, jest skłonnościąjednostki do ujmowania własnego doświadczenia w formę narracji ${ }^{5}$. Narracja rozumiana jest jako specyficzny rodzaj schematu poznawczego, obejmującego bohatera z określonymi intencjami, który napotyka na trudności w ich realizacji, a trudności te - w wyniku zdarzeń toczących się wokół zagrożonych intencji - zostają bądź nie zostają przezwyciężone. Narracja jako schemat poznawczy stanowi nie tylko reprezentację rzeczywistości, ale także zbiór procedur przetwarzania informacji jej dotyczących, także tych dotyczących emocji. Jak sugeruje Jerzy Trzebiński, „treść emocji i motywów jednostki kształtowana jest w toku interpretowania przez nią zdarzeń, w których uczestniczy, jako określonych historii”' ${ }^{\prime \prime}$ Jednostka może zatem korzystać ze strategii przeformułowania poznawczego, reinterpretując swoje doświadczenia w toku tworzonych przez nią kolejnych wersji autonarracji. Zakładam, że osoby o większej skłonności do ujmowania swoich doświadczeń w narracyjny sposób, będą również chętniej stosowały strategię regulacji emocji polegającą na przeformułowaniu poznawczym, czerpiąc przy tym korzyści związane z efektywniejszym funkcjonowaniem zawodowym.

\section{Cel badania i pytania badawcze}

Celem przeprowadzonego badania było zweryfikowanie czterech hipotez dotyczących związku pomiędzy: strategią regulacji emocji, poziomem inklinacji autonarracyjnej, a efektywnością zawodową. Hipoteza pierwsza brzmiała: istnieje związek pomiędzy strategią regulacji emocji opartą na przeformułowaniu poznawczym, a efektywnością zawodową. Im wyższa tendencja do stosowania strategii opartej na przeformułowaniu poznawczym, tym wyższa efektywność zawodowa. W przypadku alternatywnej strategii regulowania emocji, opartej na tłumieniu, założyłam związek odwrotny - im wyższa tendencja do tłumienia, tym niższa efektywność zawodowa (hipoteza druga). Hipoteza trzecia odnosiła się do związku pomiędzy inklinacją autonarracyjna, a tendencją do stosowania strategii regulacji emocji opartej na przeformułowaniu. Założyłam pozytywny związek tych zmiennych. Hipoteza czwarta mówiła o pozytywnym związku pomiędzy poziomem inklinacji autonarracyjnej a efektywnością zawodową.

\section{Procedura badania}

Przeprowadzone badanie miało charakter korelacyjny. W badaniu wzięło udział 49 pracowników (31 kobiet 18 mężczyzn) w wieku 19-55 lat, jednego z warszawskich call center. Wykształcenie oraz doświadczenie osób badanych były zróżnicowane. W badanej próbie znalazły się osoby o średnim i wyższym wykształceniu oraz studenci. Najwięcej, $39 \%$ badanych posiadało od roku do trzech lat doświadczenia w sprzedaży przez telefon. Dobór osób badanych był celowy ze względu na projekt, przy realizacji którego pracowali uczestnicy. Wybrano dwa trudne projekty sprzedażowe. Do obowiązków osób zatrudnionych przy tego typu projektach należy wykonywanie połączeń wychodzących do potencjalnych klientów oraz oferowanie im zakupu określonej usługi. Wybór tego typu projektów podyktowany był przedmiotem badania. Założyłam, że znaczenie kompetencji w zakresie regulacji emocji będzie miało większe znaczenie w sytuacjach o większym ich natężeniu - sytuacja sprzedaży, niż w sytuacjach o mniejszym natężeniu emocji, jaką może być na przykład przeprowadzanie ankiety telefonicznej, czy udzielanie informacji produktowych. W ramach projektów udział w badaniu był dobrowolny. Pracownicy poproszeni zostali o wypełnienie kwestionariusza składającego się z trzech części: pytań dotyczących danych demograficznych, Kwestionariusza Inklinacji Autonarracyjnej (IAN-R) oraz Kwestionariusza Regulacji Emocji (ERQ). Ze względu na konieczność zestawienia danych pochodzących z kwestionariuszy z obiektywnymi miarami efektywności pracy, badanie nie było anonimowe.

\section{SPOSÓB POMIARU ZMIENNYCH}

Pierwsza z badanych zmiennych, inklinacja autonarracyjna, była w badaniu weryfikowana za pomocą Kwestionariusza Inklinacji Autonarracyjnej (IAN-R) stworzonego przez Emilię Soroko7. Im wyższy wynik uzyskany w tym kwestionariuszu, tym wyższy poziom inklinacji autonarracyjnej - skłonności do ujmowania własnych doświadczeń w formę narracji

4 Y. Liu, P. L. Perrewe, L. M. Prati, R. A. Brymer, Individual differences in emotion regulation, emotional experiences at work, and work-related outcomes: A two-study investigation, "Journal of Applied Social Psychology" 2010, nr 40, s. 1515-1538.

5 E. Soroko, Wywoływanie autonarracji w badaniach psychologicznych. Ocena (auto)narracyjności wypowiedzi, Poznań 2010, s. 32-33.

6 J. Trzebiński, Narracja jako sposób rozumienia świata, Sopot 2002, s. 40.

7 E. Soroko, dz. cyt., s. 33 . 
oraz relacjonowania ich innym. Druga zmienna, strategia regulacji emocji, to sposób w jaki jednostka radzi sobie emocjami, w jaki sposób reguluje ich doświadczanie oraz ekspresję. Przyjęłam za J. Grossem, że regulacja ta zachodzić może na różnych etapach oraz być skoncentrowana na poprzedzaniu (antecedent-focused) lub na odpowiedzi (response-focused). W niniejszym badaniu zastosowałam stworzony przez J. Grossa Kwestionariusz Regulacji Emocji (ERQ), który pozwala rozróżniać osoby badane ze względu na stosowane przez nich strategie: przeformułowanie poznawcze lub tłumienie. Im wyższy wynik uzyskany w jednej z dwóch wymienionych skal, tym większa tendencja do stosowania danej strategii regulacji emocii. Trzecia zmienna, efektywność zawodowa została oszacowana na podstawie dwóch kluczowych wskaźników wykorzystywanych w branży call center. Wskaźniki te służą do oceny wydajności pracy konsultantów telefonicznych wykonujących połączenia wychodzące $\mathrm{w}$ ramach projektów sprzedażowych. Wspomniane parametry to: efektywność oraz skuteczność prowadzonych rozmów. Efektywność definiowana jest jako liczba sprzedaży w godzinie pracy. Wskaźnik ten określa zdolności konsultanta - liczbę sprzedaży oraz tempo ich realizacji. Skuteczność natomiast definiowana jest jako stosunek liczby rozmów zakończonych sprzedażą do wszystkich przeprowadzonych rozmów merytorycznych, czyli takich, w których klientowi przedstawiona została oferta. Wskaźnik ten pozwala stwierdzić, czy konsultant angażuje się w każdą rozmowę, czy każdą rozmowę próbuje zakończyć sprzedażą (wysoka skuteczność), czy wręcz przeciwnie - wykazuje niedbałość i wykonuje dużą liczbę połączeń, poszukując klientów, którzy będą zdecydowani na zakup (niska skuteczność). Optymalne wartości tych wskaźników, to zarówno wysoka efektywność, jak i wysoka skuteczność. W niniejszym badaniu, do określenia efektywności zawodowej konsultantów, zdecydowano się więc wykorzystać jeden wskaźnik, stanowiący uśredniony wynik konsultanta w zakresie efektywności i skuteczności, który nazwany został efektywnością zawodowa.

\section{WYNIKI}

Na podstawie analizy statystycznej zebranych przeze mnie danych, główne zmienne scharakteryzować można za pomocą statystyk opisowych przedstawionych w Tabeli 1., dla każdej z nich obliczono średnią oraz odchylenie standardowe.

Tabela 1. Statystyki opisowe

\begin{tabular}{|l|c|c|}
\hline Zmienna & Średnia & Odchylenie standardowe \\
\hline Inklinacja autonarracyjna & 109,76 & 20,56 \\
\hline Przeformułowanie poznawcze & 26,55 & 8,48 \\
\hline Tłumienie & 14,18 & 5,27 \\
\hline Efektywność zawodowa & 2,03 & 0,47 \\
\hline
\end{tabular}

Źródło: Opracowanie własne.

Na podstawie przeprowadzonej analizy korelacji badanych zmiennych, której wyniki przedstawiono w Tabeli 2., stwierdzić można, że strategia regulacji emocji wiąże się z efektywnością zawodową. Związek ten okazał się istotny statystycznie tylko dla strategii polegającej na tłumieniu emocji. Im wyższa tendencja do regulacji emocji poprzez ich thumienie, tym niższa efektywność zawodowa. W odniesieniu do regulacji emocji na drodze przeformułowania poznawczego, związek ten jest nieistotny. Przeformułowanie poznawcze jest związane istotnie statystycznie z poziomem inklinacji autonarracyjnej. Tak jak zakładano, związek ten jest pozytywny, im większa tendencja do stosowania przeformułowania poznawczego jako strategii regulacji emocji, tym wyższy poziom inklinacji autonarracyjnej. Inklinacja autonarracyjna nie jest jednak istotnie związana z efektywnością zawodową.

Tabela 2. Wyniki analizy korelacji

\begin{tabular}{|l|c|c|c|c|}
\hline Zmienne & \multicolumn{1}{|c|}{$\mathbf{3}$} & \\
\hline 1. Inklinacja autonarracyjna & - & & & \\
\hline 2. Przeformułowanie poznawcze &, $241^{*}$ & - & & \\
\hline 3. Tłumienie &, 012 &, $323^{*}$ & - & - \\
\hline 4. Efektywność zawodowa &,$- 268^{*}$ &,- 183 &,$- 391^{* *}$ & \\
\hline
\end{tabular}

"Korelacja jest istotna na poziomie 0,01 (jednostronnie).

"Korelacja jest istotna na poziomie 0,05 (jednostronnie)

Źródło: Opracowanie własne.

8 J.Gross, dz. cyt., s. 14. 
Aby określić względną wagę strategii regulacji emocji polegającej na tłumieniu dla efektywności zawodowej, przeprowadziłam krokową analizę regresji liniowej. W efekcie uzyskałam model zaprezentowany w Tabeli 3.

Tabela 3. Wyniki krokowej analizy regresji liniowej

\begin{tabular}{|l|l|l|l|}
\hline Model & Współczynniki standaryzowane Beta & $\mathbf{t}$ & Istotność \\
\hline Tłumienie &,- 409 & $-3,069$ &, 004 \\
\hline
\end{tabular}

Statystyka modelu: $\mathrm{F}=9,419, \mathrm{p}=, 004, \mathrm{R} 2=, 167$

Źródło: Opracowanie własne.

Jak wynika z przeprowadzonej analizy, efektywność zawodowa może być przewidywana na podstawie tendencji do posługiwania się strategią regulacji emocji polegającą na tłumieniu emocji. Im wyższa efektywnośćzawodowa, tym niższa tendencja jednostki do tłumienia emocji. Zmienna ta wyjaśnia 16,7\% wariancji efektywności zawodowej.

Wyniki uzyskane w niniejszym badaniu potwierdzają znaczenie kompetencji emocjonalnych dla efektywnego funkcjonowania zawodowego, rozumianego jako uzyskiwanie wysokich wskaźników wydajnościowych. Podobne zależności, wykazał również Malcolm Higgs9 ${ }^{9}$, wskazując na kluczowe znaczenie poszczególnych komponentów inteligencji emocjonalnej, dla funkcjonowania w trudnych emocjonalnie sytuacjach zawodowych, takich jak praca w charakterze konsultanta call center. W tego typu zadaniach, wymagających sprawnego radzenia sobie z często pojawiającymi się emocjami, tłumienie ich wydaje się być niekorzystne z wielu powodów. Jednym z mechanizmów wyjaśniających ten negatywny związek może być tzw. efekt wyczerpania ego (ego-depletion). Efekt ten opisywany przez Roya Baumeistera, polega na pogorszeniu się wskaźników wykonania kolejnego zadania, pod wpływem wcześniejszego zaangażowania w zadanie wymagające wysiłku ${ }^{10}$. W tym energetycznym ujęciu, pracownicy tłumiący emocje, wydatkują ograniczone zasoby ego na hamowanie emocji, co może prowadzić do spadku wydolności w radzeniu sobie z ich podstawowym zadaniem zawodowym, jakim jest zachęcenie klienta do zakupu. Innym wyjaśnieniem obniżenia efektywności zawodowej może być, sugerowany przez Sławomira Śpiewaka, mechanizm związany z kosztami poznawczymi wynikającymi ze zmiany charakteru aktywności. Tłumienie emocji może wchodzić w konflikt ze specyfiką kolejnej aktywności, która w przeciwieństwie do pierwszej thumienia, polega na aktywnym podtrzymaniu czynności wysiłkowej- wykonaniu zadania, sprzedaży ${ }^{11}$.Związek drugiej $\mathrm{z}$ badanych zmiennej - inklinacji autonarracyjnej z efektywnością zawodowa, jak już wspomniano, okazał się nieistotny statystycznie. Wyjaśnieniem uzyskanego wyniku może być fakt, że tendencja do ujmowania własnych doświadczeń w formę narracji odnosi się do przeżyć osobiście ważnych dla człowieka, pełniąc istotną rolę w integrowaniu tożsamości. Praca w charakterze konsultanta call center, dla wielu osób zatrudnionych na tym stanowisku, jest zadaniem przejściowym lub dodatkowym. W związku z tym, niewielu pracowników uznawać je może za ważne, wymagające refleksji, w tym refleksji o charakterze narracyjnym. Warto przeprowadzić szersze badania, w które zaangażowane będę różne grupy zawodowe, aby zweryfikować to przypuszczenie i móc jednoznacznie określić wpływ inklinacji autonarracyjnej na sprawność funkcjonowania w pracy. Niewykluczone także, że narratyzacja doświadczeń pełni ważniejszą rolę w odniesieniu do takich zmiennych, jak na przykład satysfakcja z pracy, niż w przypadku uwzględnionych w niniejszym badaniu, zmiennych o charakterze jedynie wydolnościowym. Jest to kolejny, wyłaniający się obszar badawczy. Dotychczasowe badania nad dobroczynnym wpływem narracji prowadzone były głównie w nurcie klinicznym. Szczególnie ciekawym wynikiem przeprowadzonego badania jest pozytywny związek inklinacji autonarracyjnej ze strategią regulacji emocji polegającą na przeformułowaniu poznawczym. Wyniki te sugerują, że przeformułowanie poznawcze zachodzić może dzięki naturalnej skłonności ludzi do ujmowania swoich doświadczeń w narracyjny sposób. Silniejsza tendencja do ujawniania takiego sposobu integracji własnych doświadczeń, związana jest z większym repertuarem dostępnych epizodów historii, w ramach który doświadczenie emocjonalne może zostać ujęte, tym samym, jednostce łatwiej jest zinterpretować własną sytuację w alternatywny sposób. Ponadto, jak wskazuje J. Gross, rozwój kompetencji w zakresie regulowania emocii na drodze przeformułowania poznawczego warunkowany jest zdobywaniem wiedzy na temat: okoliczności w jakich dochodzi do wzbudzenia emocji, ich przyczyn, zasad ekspresji oraz sekwencji doświadczania (emotion scripts) ${ }^{12}$. Wiedza

9 M. Higgs, A study of the relationship between emotional intelligence and performance in UK call centres, "Journal of Managerial Psychology" 2004, nr 19, s. 442-454

10 R. Baumeister, Ego depletion and self-control failure: An energy model of the self's executive function, "Self and Identity" 2002, nr 1, s. 129-136.

11 S. Śpiewak, Rozgrzewanie uwagi-wyczerpywanie woli-uległość, Warszawa 2013, s. 226-233.

12 J. Gross, dz. cyt., s. 21. 
o emocjach przekazywana jest i współkształtowana poprzez narracje rodziców, rówieśników i innych osób znaczących. Powyższe wyjaśnienie związku inklinacji autonarracyjnej i regulacji emocji, z wykorzystaniem przeformułowania poznawczego, wymaga kolejnych badań oraz gruntownej weryfikacji. Kluczowe wydaje się nie tylko dogłębne poznanie charakteru związku tych zmiennych, ale także sfer zawodowego funkcjonowania człowieka, dla których mogą mieć one istotne znaczenie. Niniejsze badanie wykazało bowiem, że nie przekładają się one wprost na efektywność zawodowa, w prostym, wydajnościowym ujęciu.

\section{Bibliografia}

[1] Baumeister R., Ego depletion and self-control failure: An energy model of the self's executive function, "Self and Identity" 2002

[2] Diefendorff J. M., Richard E. M., Yang J., Linking emotion regulation strategies to affective events and negative emotions at work, "Journal of Vocational Behavior" 2008, $\mathrm{nr} 73$.

[3] Grandey A. A., Emotion regulation in the workplace: A new way to conceptualize emotional labor, "Journal of Occupational Health Psychology" $2000, \mathrm{nr} 5$.

[4] Grandey A. A., Fisk G. M., Steiner D. D., Must "service with a smile" be stressful? The moderating role of personal control for American and French employees, "Journal of Applied Psychology" 2005, nr 90

[5] Gross J., Handbook of emotion regulation, New York 2009.

[6] Higgs M., A study of the relationship between emotional intelligence and performance in UK call centres, "Journal of Managerial Psychology" 2004, nr 19 .

[7] Liu Y., Perrewe P. L., Prati L. M., Brymer R. A., Individual differences in emotion regulation, emotional experiences at work, and work-related outcomes: A two-study investigation, "Journal of Applied Social Psychology" 2010, nr 40.

[8] Salovey P., Mayer J. D., Emotional Intelligence, "Imagination, Cognition And Personality" 1989.

[9] Soroko E., Wywotywanie autonarracji w badaniach psychologicznych. Ocena (auto)narracyiności wypowiedzi, Poznań 2010.

[10] Śpiewak S., Rozgrzewanie uwagi-wyczerpywanie woli - uległość, Warszawa 2013.

[11] Totterdall P., Holman D., Emotion regulation in customer service roles: testing a model of emotional labor, "Journal of Occupational Health Psychology" 2003, nr 8.

[12] Trzebiński J., Narracja jako sposób rozumienia świata, Sopot 2002. 